\title{
The Importance of a Lipopolysaccharide-initiated, Cytokine-mediated Host Defense Mechanism in Mice against Extraintestinally Invasive Escherichia coli
}

\author{
Alan Cross, Ludmila Asher, Matthew Seguin, * Liang Yuan, Niamh Kelly, Craig Hammack, Jerald Sadoff, \\ and Peter Gemski, Jr. \\ *The Departments of Bacterial Diseases and Immunology and the Division of Pathology, Walter Reed Army Institute of Research \\ Washington, DC 20307-5100
}

\begin{abstract}
Extraintestinally invasive Escherichia coli (EC) that possess both a complete LPS and $K 1$ capsule evade both complement-mediated bacteriolysis and neutrophil-mediated killing. Since C3H/HeJ mice that are hyporesponsive to LPS were uniquely susceptible to lethal infection with EC of this phenotype, we speculated there was an LPS-initiated host defense mechanism against this pathogenic phenotype. The LPS-normoresponsive $\mathrm{C} 3 \mathrm{H} / \mathrm{HeN}$ as well as the $\mathrm{C} 3 \mathrm{H} / \mathrm{HeJ}$ mice cleared these EC from the circulation within $4 \mathrm{~h}$ of intravenous administration. Whereas electron micrographs of the liver demonstrated these EC undergoing degeneration within the phagolysosomes of of both macrophages and Kupffer cells of $\mathrm{C} 3 \mathrm{H} / \mathrm{HeN}$ mice, these $\mathrm{EC}$ replicated within these cells of the $\mathrm{C3H} / \mathrm{HeJ}$ mice. Restoration of anti-EC activity of $\mathrm{C} 3 \mathrm{H} / \mathrm{HeJ}$ mice occurred with activation of Kupffer cells and peritoneal macrophages in vivo with BCG and in vitro with IFN- $\gamma$, but not with LPS. Pretreatment of $\mathrm{C3H} /$ HeJ mice with a combination of recombinant murine IL-1 and TNF- $\alpha$ also restored the killing of $\mathrm{K1}^{+}$-EC but did not enhance the killing of a $\mathrm{K1}^{-}-\mathrm{EC}$ mutant. These data are consistent with the hypothesis that $(a)$ there is no intrinsic inability of $\mathrm{C} 3 \mathrm{H} / \mathrm{HeJ}$ phagocytes to kill $\mathrm{EC}$, but $(b)$ an LPS-initiated, cytokine-mediated host defense mechanism is required for such killing. These studies emphasize the importance of bacterial surface characteristics in the interaction with specific host defenses. (J. Clin. Invest. 1995. 96:676-686.) Key words: sepsis • bacteremia • endotoxin • C3H mice • macrophage
\end{abstract}

\section{Introduction}

Successful pathogens with abilities to evade a variety of host defense mechanisms can invade host tissue, replicate, and disseminate from the site of initial invasion (1-3). Complement-mediated bacteriolysis is a highly efficient host defense mechanism that is effective against bacteria that lack an acid polysaccharide capsule (4-7) and have a rough, part-rough, or incomplete, LPS phenotype

Address correspondence Alan S. Cross, Division of Infectious Diseases, Department of Medicine, University of Maryland School of Medicine and Program in Oncology, University of Maryland Cancer Center, 22 South Greene Street, Baltimore, MD 21201-1595. Phone: 410-328-2565; FAX: 410-328-6896.

Received for publication 5 June 1992 and accepted in revised form 24 May 1995.

The Journal of Clinical Investigation, Inc.

Volume 96, August 1995, 676-686
(8-11). The clinical relevance of this mechanism was first demonstrated by Roantree and colleagues who reported that $>95 \%$ of strains retrieved from patients with bacteremia were able to resist the lethal effects of serum $(12,13)$. This observation has been amply confirmed by other investigators (14-16).

Neutrophil-mediated opsonophagocytic killing of bacteria is another defense mechanism by which invading bacteria are controlled by the host. In contrast to their ability to resist serummediated lysis, most bacteremic Escherichia coli are susceptible to opsonophagocytic killing. In a survey of over 200 consecutive bacteremic isolates of $E$. coli, most strains lacking a K1 capsule, regardless of LPS phenotype, were easily killed by fresh, normal human serum in conjunction with normal human neutrophils (14). K1-encapsulated strains (and to a lesser extent K12- and K53-encapsulated strains), however, were poorly killed by this mechanism. Even among these opsonophagocytic resistant strains, those having a complete or smooth LPS phenotype were more resistant than those with a rough or part rough LPS phenotype.

These opsonophagocytosis-resistant, K1-encapsulated $E$. coli comprise $>20 \%$ of all bacteremic strains (14-17), yet the mortality in adults after infection with these strains is no greater than infection with non-K1-encapsulated $E$. coli. This suggests that other defense mechanisms might be available to the host for overcoming infection with serum-resistant bacteria that are not susceptible to neutrophil-mediated killing.

We have previously shown that $\mathrm{C} 3 \mathrm{H} / \mathrm{HeJ}$ mice that are blocked in their ability to respond normally to LPS are highly susceptible to lethal infection after challenge with low levels of K1-encapsulated bacteria possessing a smooth LPS phenotype (18). The administration of the combination recombinant murine TNF- $\alpha$ and IL- $\alpha$, however, protected these mice from $>10$ $\mathrm{LD}_{50}$ bacterial challenge. In contrast, $\mathrm{C} 3 \mathrm{H} / \mathrm{HeN}$ mice whose responses to LPS were intact were significantly more resistant to lethal infection with the same organism. These data suggested that an LPS-mediated induction of a cytokine response might be an additional host defense mechanism against $E$. coli.

In the present study we show that such a cytokine-mediated defense mechanism might be a generalized, bacterial host response to bacteria that have both a smooth LPS phenotype and $\mathrm{K} 1$ polysaccharide capsule, characteristics that permit the organism to evade serum bacteriolysis and neutrophil-mediated killing. Further, we show that such a cytokine-mediated defense mechanism optimally requires an activated macrophage and fresh normal serum. A practical implication of a beneficial, LPS-initiated host response is that modification of this mechanism (as might occur with treatment of patients with antibody to TNF or with IL-1 receptor antagonist, or after the induction of tolerance to LPS) might increase morbidity and mortality in those patients with bacteremia, but who are not in shock and who require an intact host defense mechanism to overcome the bacterial infection. 


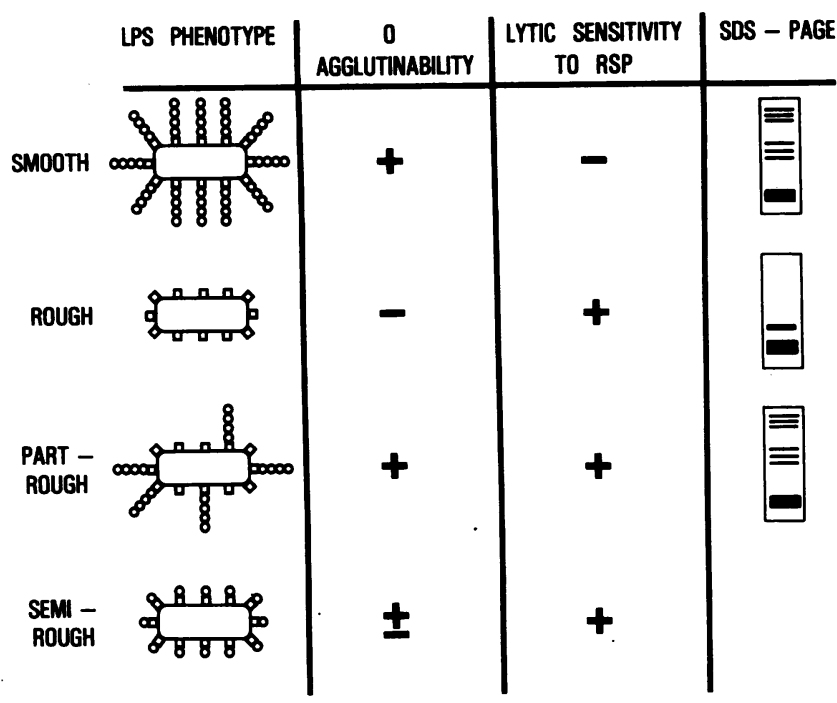

Figure 1. Definition of LPS phenotypes. The LPS phenotype, depicted schematically on bacilli by core (squares) and polysaccharide repeat units (circles), can be defined on the basis of its reaction to O-specific antisera, susceptibility to lysis by rough-LPS specific bacteriophages $(R S P)$, and appearance on SDS-PAGE.

\section{Methods}

Bacteria. E. coli 0.18:K1:H7, strain Bort (originally provided by Dr. George Siber, Dana-Farber Cancer Institute, Boston, MA), and a K1negative mutant have been previously described (19). Rough LPS, K1positive mutants of the parental strain were derived by Tn10 mutagenesis (20). E. coli strains $221,412,623,646,736,781,854,888$ were originally isolated from the blood or spinal fluid of patients at Walter Reed Army Medical Center, Washington, DC, and were stored in skim milk at $-20^{\circ} \mathrm{C}$ until use. All isolates were serotyped by Drs. Frits and Ida Orskov (Statenseruminstitut, Copenhagen, Denmark). Klebsiella strains B5055 (01:K2) and Friedlander $201(01: \mathrm{K}-)$ were originally obtained from Drs. Ida and Frits Orskov. All bacteria were grown for single colony isolation on tryptic soy agar overnight at $37^{\circ} \mathrm{C}$. These cultures were then further cultured in tryptic soy broth to log phase growth, washed two times in PBS, and adjusted spectrophotometrically to the desired concentration for subsequent studies.

Bacteriophages. Rough-LPS specific bacteriophages (C21, Ffm, BR60, BR2, 6SR) were originally obtained from Dr. Bruce Stocker (Stanford University, Stanford, CA) and used as previously described (19). The rough or part-rough LPS phenotype was defined as the ability of any one of these bacteriophages to cause lysis of a lawn of bacterial cells. Part-rough LPS strains were typable by agglutination with $O$ antisera and had a typical "ladder" appearance on SDS-PAGE (Fig. 1). K1-specific bacteriophages (A-E) were originally obtained from Dr. Bernard Rowe (Central Public Health Laboratory, London, United Kingdom) and used as previously described (19). Lysis of a lawn of bacteria with any one of these phages defined a K1-positive strain. K1negative mutants of parental $\mathrm{K} 1$-encapsulated strains were selected as single colonies that resisted phage lysis and grew in the lytic plaque. Such single colony isolates were subcultured and confirmed as K1negative $E$. coli.

Mice. Female LPS-hyporesponsive $\mathrm{C} 3 \mathrm{H} / \mathrm{HeJ}$ mice (5-6 wk old) were obtained from The Jackson Laboratories (Bar Harbor, ME). LPS normoresponsive $\mathrm{C} 3 \mathrm{H} / \mathrm{HeN}$ mice were obtained from Harlan-Sprague Dawley Inc. (Indianapolis, IN). Both groups of mice were used between 9 and 12 wk of age. $L D_{50}$ determinations were done on groups of fiveseven mice by injecting graded concentrations of bacteria intraperitoneally in a volume of $0.1 \mathrm{ml}$ and observing for $14 \mathrm{~d}$. Calculations were done according to the method of Reed and Muench (21). $\mathrm{LD}_{50}$ determi- nations were also performed on mice pretreated with $2 \times 10^{5}$ live BCG (Calbiochem Corp., La Jolla, CA) administered intraperitoneally in 0.1 $\mathrm{ml}$ vol 7-10 d before bacterial challenge with $E$. coli $018: \mathrm{K} 1$, strain Bort. In some experiments, mice were pretreated with cobra venom factor (CVF; ${ }^{1}$ Cordis Laboratories, Miami, FL) to transiently deplete them of complement (22). $24 \mathrm{~h}$ before bacterial challenge (and $22 \mathrm{~h}$ before cytokine pretreatment with recombinant murine IL- $1 \alpha$ and TNF$\alpha$, both obtained from Genzyme, Boston, MA) cobra venom factor was given intraperitoneally at a dose of $300 \mathrm{mU}$ per gram weight. Control groups included CVF-treated mice that were not given bacterial challenge.

Isolation of Kupffer cells. Murine Kupffer cells (KC) were isolated as previously described (23). Briefly, mice were euthanized with $2 \mathrm{mg}$ intraperitoneal pentobarbital, and the livers were perfused through the inferior vena cava with $50 \mathrm{ml} \mathrm{Ca}{ }^{2+}$ and $\mathrm{Mg}^{2+}$-free $\mathrm{HBSS}$ (GIBCO, Gaithersburg, MD), followed by $50 \mathrm{ml}$ of type IV collagenase $(0.2 \mathrm{mg} /$ $\mathrm{ml}$, Sigma Chemical Co., St. Louis, MO) in RPMI 1640. The liver was excised, rinsed in cold RPMI 1640, and disaggregated by teasing with forceps. Parenchymal cells were removed by sequential centrifugations at $4^{\circ} \mathrm{C}(50 \mathrm{~g}$ for $4 \mathrm{~min}$, then $150 \mathrm{~g}$ for $10 \mathrm{~min})$. The cell pellet was suspended in lysis buffer $\left(0.16 \mathrm{M} \mathrm{NH}_{4} \mathrm{Cl}, 10 \mathrm{mM} \mathrm{KHCO}, 0.1 \mathrm{mM}\right.$ DiNa-EDTA), centrifuged at $150 \mathrm{~g}$ for $10 \mathrm{~min}$, and resuspended in assay medium (RPMI 1640 with $10 \%$ FBS, $25 \mathrm{mM}$ Hepes buffer, 2 mM 1-glutamine, [GIBCO]). Typically, 3-7 × $10^{6} \mathrm{Kupffer}$ cells were obtained from a single mouse.

Light and electron microscopy. Samples of liver were fixed in $10 \%$ buffered formalin for light microscopy. Tissues were embedded in paraffin and sections were stained with hematoxylin and eosin, periodic acid Schiff, Giemsa and Brown-Brenn procedures. For electron microscopy, liver tissue was fixed in a mixture of $4 \%$ formaldehyde and $1 \%$ glutaraldehyde (4 FIG), postfixed in $1 \%$ osmium tetroxide, dehydrated through graded alcohols, and embedded in Epon. Thin sections were stained with uranyl acetate and lead citrate and examined with an electron microscope (109; Carl Zeiss Inc., Thornwood, NY).

In vitro opsonophagocytic bacterial killing assay. Mice were treated with proteose-peptone $(5 \mathrm{mg}$ in $1.0 \mathrm{ml}$ intraperitoneally, Sigma Chemical Co. for 3-5 days). Cells were harvested from the peritoneum by washing the peritoneum with cold buffer, low speed centrifugation of the recovered wash fluid, and washing and pooling the cells from the individual mice of a given strain. For some assays, Kupffer cells, obtained as described above, were used as the phagocytic cell. The pooled peritoneal macrophages or Kupffer cells were suspended to a concentration of $2 \times 10^{6}$ cells $/ \mathrm{ml}$ in DME (GIBCO) supplemented with $10 \%$ heat-inactivated FCS (Sigma Chemical Co.), penicillin and streptomycin. Cells were added to a 96-well flat-bottomed, polystyrene tissue culture plate (Costar Corp., Cambridge, MA) at $2 \times 10^{5}$ per well. For activation of the cells, recombinant murine IFN- $\gamma(\mathrm{r}$ muIFN- $\gamma$ Genzyme Corp., Boston, MA), recombinant macrophage-colony stimulating factor (M-CSF) (kindly provided by Dr. Mark Garnick, Genetics Institute, Cambridge, MA), recombinant TNF- $\alpha$ and recombinant human IL- $1 \alpha$ (both purchased from Genzyme Corp.), or LPS prepared by hot phenolwater extraction (24) from the Bort strain was added. In preliminary experiments, a concentration of $50-100 \mathrm{U} / \mathrm{ml} \mathrm{r} \mathrm{muIFN- \gamma}$ was found to be optimal for priming, while $0.1-10 \mu \mathrm{g} / \mathrm{ml}$ LPS induced activation in the macrophages. This resulted in an induction of $87 \%-99 \%$ phagocytemediated killing over this range of LPS priming. In the absence of $10 \%$ FCS in the incubation mixture, $\sim 10$-fold more LPS was required to achieve the same level of bacterial killing (data not shown). Endotoxin levels in the culture system were monitored with a turbidometric Limulus lysate assay (LAL 5000; Associates of Cape Cod, Falmouth, MA) and found to be $<90 \mathrm{pg} / \mathrm{ml}$ in those wells to which LPS was not intentionally added.

These cells were then incubated at $37^{\circ} \mathrm{C}$ in a $5 \% \mathrm{CO}_{2}$ atmosphere

1. Abbreviations used in this paper: CVF, cobra venom factor; M-CSF, recombinant macrophage CSF; $r$ muIFN- $\gamma$, recombinant murine IFN- $\boldsymbol{\gamma}$. 
for 48-72 h. After this preincubation or "priming" step, the cells were washed three times in cold RPMI 1640 to rid the cultures of antibiotics, FCS, and macrophage priming agent. Bacteria $\left(1 \times 10^{4} \mathrm{CFU}\right.$ at a bacteria to cell ratio of $1: 20$ ) were added to the macrophage monolayer in the presence of $20 \%$ fresh normal human serum diluted in RPMI 1640. A sample of this incubation mixture was obtained for colony count. The bacteria were then centrifuged onto the monolayer (30 min at $4^{\circ} \mathrm{C}$ at $500 \mathrm{~g}$ ) to improve bacteria-phagocyte contact. The mixture was then incubated for $30 \mathrm{~min}$ at $37^{\circ} \mathrm{C}$ to permit uptake of the bacteria by the phagocytes. A second aliquot was sampled from the supernatant to assess the initial uptake of bacteria by the phagocytes. This point in the assay procedure was defined as the " 0 time," and a set of cells was lysed in distilled water (after removal of supernatant) and samples were plated on tryptic soy agar for baseline ( 0 time) colony counts. The microtiter plate was then incubated for $3 \mathrm{~h}$ at $37^{\circ} \mathrm{C}$ in $\mathrm{CO}_{2}$ at the end of which time the supernatants were removed, $100 \mu$ l distilled water were added to the cells for $10 \mathrm{~min}$ and mixed and diluted before plating $10 \mu \mathrm{l}$ in duplicate from each well for colony counts onto tryptic soy agar. Duplicate aliquots were obtained from triplicate wells for each variable. All plates were then cultured overnight at $37^{\circ} \mathrm{C}$ and colony counts enumerated. The mean CFU of the six samples was multiplied by the dilution factor and expressed as CFU per milliliter.

Assay for cell surface markers by flow cytometry. Kupffer cells and peritoneal macrophages were prepared from $\mathrm{C} 3 \mathrm{H} / \mathrm{HeJ}$ and $\mathrm{C} 3 \mathrm{H} / \mathrm{HeN}$ mice as described above. The cells were prepared for analysis by fixation in $1 \%$ paraformaldehyde and blocking with rat anti-mouse Fc receptor $\gamma 2$ and 3 (FcBlock; Pharmingen, San Diego, CA). Incubation with the indicated $\mathrm{mAb}$ was then carried out in individual tubes for $30 \mathrm{~min}$ at $4 \mathrm{C}$, washed twice and resuspended in $500 \mathrm{ul}$ of PBS. For assessment of expression of CR4, cells were first incubated with the unconjugated mAb (BU15, AMAC, Westbrook, ME) or mouse $\mathrm{IgG}_{1}$ isotype control ( $m A b ~ S_{1}-68.1$, Pharmingen, San Diego, CA) and then with fluorescein conjugated goat anti-mouse antibody (F-GAM; Sigma Chemical Co.) as the secondary antibody (second incubation in the dark for $\mathbf{3 0 ~} \mathrm{min}$ at $4^{\circ} \mathrm{C}$ ). Control cells for these experiments were incubated with isotype control $\mathrm{mAb}$ or with no $\mathrm{mAb}$ (to assess autofluorescence). An additional control for nonspecific binding was also run in which secondary antibody (F-GAM) was added in the absence of primary antibody.

The samples were analyzed on a FACSort flow cytometer (Becton Dickinson and Co., Mountain View, CA) that had a 15-mW, 488-nm air-cooled argon-ion laser. Daily performance of the instrument was monitored by running CaliBRITE beads (Becton Dickinson and Co.) using the Autocomp software (Becton Dickinson and Co.). This software program optimizes forward and side scatter settings to distinguish populations of lymphocytes from monocytes and granulocytes based on their size and granularity, respectively. The flow cytometer was gated to exclude lymphocytes, granulocytes, and nonviable cells. The Kupffer and peritoneal macrophage populations studied were $99 \%$ positive for HLA-DR and 83\% positive for CD14 (clones L243 and Leu-M3 respectively; Becton Dickinson and Co.). A total of 5,000 events per sample was measured using FACSort@ LYSIS II software (Becton Dickinson and Co.). Events were collected using four-decade log amplification. Electronic compensation was used to remove residual spectral overlap of the green fluorescence channel and red fluorescence channel. Data were analyzed on a HP 9000 series model 340 computer (HewlettPackard Co., Palo Alto, CA) and dot plots and histograms were generated using LYSYS II software. The mean channel fluorescence intensity for the isotypic control mAb always equalled or slightly exceeded the low level of cell autofluorescence and therefore represented a true background reading.

\section{Results}

We determined the $\mathrm{LD}_{50}$ of bacteremic $E$. coli strains of various phenotypes in LPS-hyporesponsive $\mathrm{C} 3 \mathrm{H} / \mathrm{HeJ}$ mice to insure that the increased susceptibility to lethal infection of these mice was not limited to one unusually virulent strain. As shown in
Table I. Ability of Different Bacteremic Strains of E. coli to Kill C3H/HeJ (LPS-Hyporesponsive) Mice

\begin{tabular}{llcc}
\hline $\begin{array}{c}\text { Challenge } \\
\text { strain }\end{array}$ & \multicolumn{1}{c}{ Serotype } & $\begin{array}{c}\text { Rough-phage* } \\
\text { sensitivity }\end{array}$ & $\begin{array}{c}\mathrm{LD}_{5_{0}}{ }^{7} \\
\text { (CFU) }\end{array}$ \\
\hline Bort & O18:K1 & - & $<10$ \\
Bort mutant & O18:K- & - & $1 \times 10^{5}$ \\
Bort Tn10 & O18:K1 & + & $7.1 \times 10^{6}$ \\
221 & O18:K1 & - & $2.6 \times 10^{4}$ \\
854 & O18:K1 & + & $1 \times 10^{7}$ \\
888 & O1:K1 & - & $8.2 \times 10^{3}$ \\
646 & O1:K1 & + & $3.1 \times 10^{8}$ \\
623 & O1:K51 & - & $>1.3 \times 10^{8}$ \\
736 & O18:K5 & - & $4.9 \times 10^{5}$ \\
412 & O nontypable:K1 & + & $>1.2 \times 10^{8}$ \\
B5055 & Klebsiella O1:K2 & ND & $<19$ \\
& Klebsiella O1:K- & ND & $>1.5 \times 10^{8}$ \\
& & & \\
\hline
\end{tabular}

* (-) indicates no lysis by the rough specific phages BR60, BR2, or Ffm; $(+)$ indicates lysis by at least one of these phages. ${ }^{\ddagger}$ Determined at $7 \mathrm{~d}$. Parental strain altered by Tn10 mutagenesis (19).

Table I, expression of a virulence phenotype even varied among smooth K1-positive isolates. Although highly virulent (strains 221,888 ), they were not as virulent as $E$. coli $018: \mathrm{K} 1: \mathrm{H} 7$, strain Bort which had been selected from a large collection of extraintestinally invasive clinical isolates based on its particular virulence in an animal model (25).

Just as with part-rough or K1-negative isolates (Table I), mutants of strain Bort that either lacked the K1 capsule or had a rough LPS, $\mathrm{K} 1^{+}$phenotype were less virulent than the parental strain. A K1-encapsulated strain that expressed a deep rough LPS phenotype (E412) had an $\mathrm{LD}_{50}$ that was over six logs greater than that for strain Bort. In addition, this association of phenotype to virulence was not limited only to $E$. coli. A serumresistant, phagocytosis-resistant strain of Klebsiella, O1:K2, had an $\mathrm{LD}_{50}$ in $\mathrm{C} 3 \mathrm{H} / \mathrm{HeJ}$ mice $<19 \mathrm{CFU}$, whereas a different Klebsiella isolate having the same $\mathrm{O}$ serogroup, but lacking the $\mathrm{K} 2$ capsule, had an $\mathrm{LD}_{50}>1.5 \times 10^{8} \mathrm{CFU}$.

Clearance studies. E. coli with a complete LPS phenotype and $\mathrm{K} 1$ capsule were the most virulent bacterial phenotype in $\mathrm{C} 3 \mathrm{H} / \mathrm{HeJ}$ mice. Since these surface characteristics facilitate the ability to evade bacterial uptake by phagocytes in vitro (14, 26 ), we next determined whether the difference in susceptibility of the $\mathrm{C} 3 \mathrm{H} / \mathrm{HeJ}$ and the LPS normoresponsive $\mathrm{C} 3 \mathrm{H} / \mathrm{HeN}$ mice to lethal infection might be explained by differences in their ability to clear $E$. coli, strain Bort, after intravenous injection. When $\mathrm{C} 3 \mathrm{H} / \mathrm{HeJ}$ mice were challenged with a dose of Bort below the $\mathrm{LD}_{50}\left(1 \times 10^{3} \mathrm{CFU}\right)$ essentially all the bacteria were removed from the blood by $30 \mathrm{~min}$ and the blood remained sterile for $21 \mathrm{~d}$. At a bacterial dose of $1 \times 10^{5} \mathrm{CFU}$, (i.e., below the $\mathrm{LD}_{50}$ for the $\mathrm{C} 3 \mathrm{H} / \mathrm{HeN}\left[2 \times 10^{6} \mathrm{CFU}\right.$ intravenously $]$, but threefold greater than the $\mathrm{LD}_{50}$ for the $\mathrm{C} 3 \mathrm{H} / \mathrm{HeJ}$ mice $\left[3 \times 10^{4}\right.$ CFU intravenously]), however, both groups of mice effectively cleared the bacteria from the bloodstream during the first $4 \mathrm{~h}$ (Fig. 2). After $12 \mathrm{~h}$, however, E. coli, strain Bort, reappeared in the blood circulation of both groups of mice. The quantitative counts of bacteria increased rapidly in all of the $\mathrm{C} 3 \mathrm{H} / \mathrm{HeJ}$ mice until death at $48 \mathrm{~h}$. In contrast, with the $\mathrm{C} 3 \mathrm{H} / \mathrm{HeN}$ mice, the bacteria reappeared at a persistently low level $(<1,000 \mathrm{CFU} /$ 


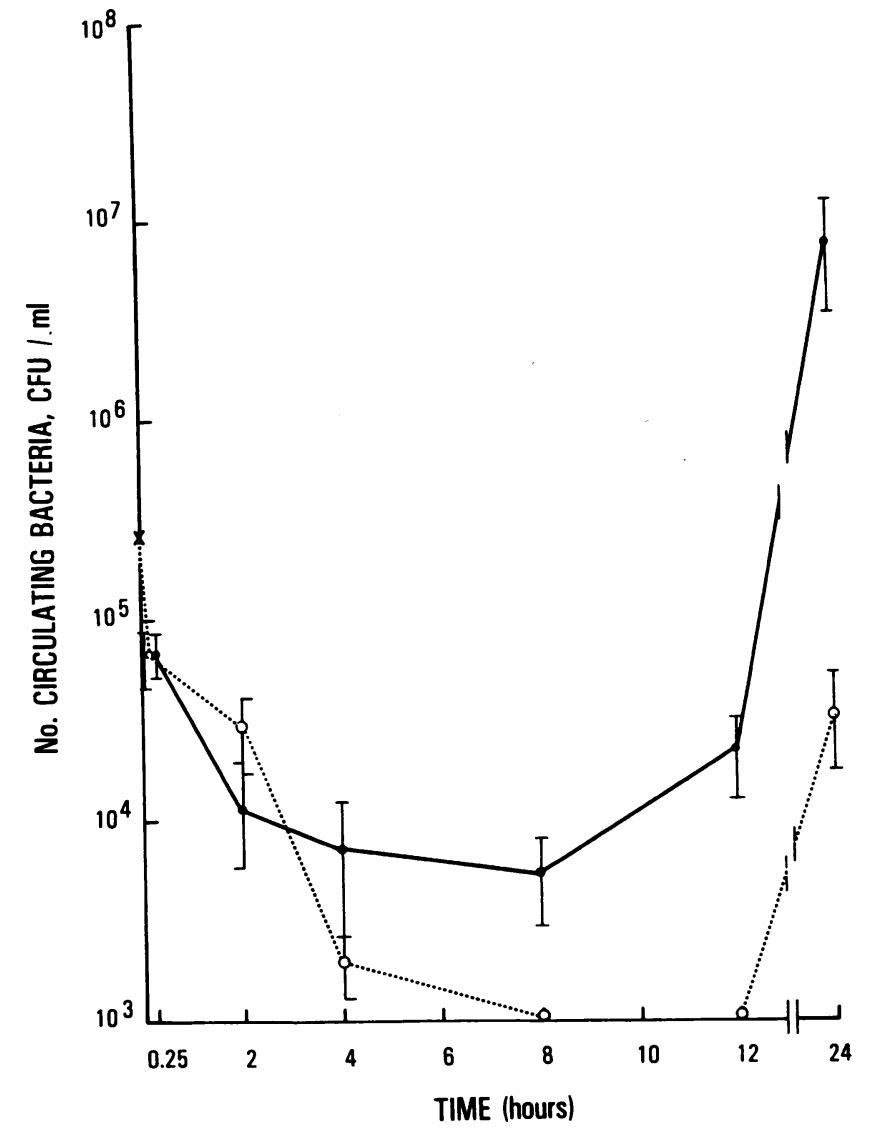

Figure 2. Clearance of $E$. coli $018: \mathrm{K} 1: \mathrm{H} 7$, strain Bort, from the peripheral circulation of $\mathrm{C} 3 \mathrm{H} / \mathrm{HeJ}$ and $\mathrm{C} 3 \mathrm{H} / \mathrm{HeN}$ mice. $\mathrm{Log}$ phase culture $\left(\sim 2 \times 10^{5} \mathrm{CFU}\right)$ was inoculated into the tail veins of $\mathrm{C} 3 \mathrm{H} / \mathrm{HeJ}$ $(\bullet--\bullet)$ and $\mathrm{C} 3 \mathrm{H} / \mathrm{HeN}(\mathrm{O} \ldots \mathrm{O})$ mice. Blood, obtained at the indicated time, was quantitatively cultured. The data points represent the mean and standard error of three mice per group.

$\mathrm{ml}$ ) in the circulation of $\mathrm{C} 3 \mathrm{H} / \mathrm{HeN}$ mice for $10 \mathrm{~d}$. These $\mathrm{C} 3 \mathrm{H} /$ $\mathrm{HeN}$ mice appeared healthy and remained active. Although no pathogens were recovered from the blood after day 10, organ cultures done at $21 \mathrm{~d}$ revealed viable bacteria in both the spleen and liver $\left(5.6 \times 10^{4}\right.$ and $7.1 \times 10^{4} \mathrm{CFU} /$ grams of tissue, respectively).

We also compared the ability of $\mathrm{C} 3 \mathrm{H} / \mathrm{HeN}$ and $\mathrm{C} 3 \mathrm{H} / \mathrm{HeJ}$ mice to clear an unencapsulated mutant of $E$. coli, strain Bort. After intravenous challenge with $1 \times 10^{6} \mathrm{CFU}$, both strains of mice cleared $>99 \%$ of bacteria by $30 \mathrm{~min}$. Some mice in each group had detectable organisms at $24 \mathrm{~h}$, but by $48 \mathrm{~h}$ the challenge strains were no longer recovered and the mice appeared healthy. Thus, $\mathrm{C} 3 \mathrm{H} / \mathrm{HeJ}$ mice were able to clear a smooth LPS, $\mathrm{K}^{-}$phenotype of $E$. coli from the circulation, whereas they were unable to resist the K1-encapsulated parental strain at this same dose.

These clearance studies revealed different abilities of the murine host to limit infection based on $(a)$ phenotype of bacteria (K1-positive or -negative) and (b) ability of mice to respond to $\mathrm{LPS}(\mathrm{C} 3 \mathrm{H} / \mathrm{HeJ}$ vs $\mathrm{C} 3 \mathrm{H} / \mathrm{HeN})$. Further, the capacity to clear a given inoculum was dose related $\left(10^{5}\right.$ vs $10^{3} \mathrm{CFU}$ in $\mathrm{C} 3 \mathrm{H} /$ HeJ mice) and related to the $\mathrm{LD}_{50}$.

Studies of Kupffer cells. Bull had shown over a half-century ago that intravenously infused bacteria were efficiently removed from the blood by the reticuloendothelial system (27). Since the clearance studies indicated that $\mathrm{C} 3 \mathrm{H} / \mathrm{HeJ}$ mice, after an initial clearance phase, were unable to maintain an adequate, ongoing clearance of the K1-encapsulated $E$. coli from the circulation, we examined the ability of Kupffer cells, the fixed tissue macrophages, and primary phagocyte of the liver, to ingest strain Bort and its K1-negative mutant.

Colony counts performed on liver homogenates revealed that the K1-positive, wild-type strain Bort, was detected in significantly higher levels in the $\mathrm{C} 3 \mathrm{H} / \mathrm{HeJ}$ than in the $\mathrm{C} 3 \mathrm{H} / \mathrm{HeN}$ mice (a mean of 1,376 CFU/mg liver from three $\mathrm{C} 3 \mathrm{H} / \mathrm{HeJ}$ mice vs a mean of $10 \mathrm{CFU} / \mathrm{mg}$ liver from $\mathrm{C} 3 \mathrm{H} / \mathrm{HeN}$ mice). In contrast to this K1-positive strain, the K1-negative mutant of Bort was killed by both groups of mice (no viable bacteria in liver homogenates, data not shown), suggesting that either this bacterial phenotype could be efficiently taken up and killed by phagocytes in the liver, or, alternatively, that other host defense mechanisms, such as those mediated by neutrophils, were able to kill bacteria of this phenotype before they reached the liver.

Although culture of liver homogenates is likely to reflect the ability of the Kupffer cell population in the liver to ingest and kill $E$. coli, we wished to address this more directly. Mice were next challenged intraperitoneally with $1 \times 10^{6} \mathrm{CFU}$ of strain Bort and their Kupffer cells were isolated and cultured $10 \mathrm{~h}$ later. Similar to the observations with liver homogenates, few K1-encapsulated bacteria were recovered from the Kupffer cells of $\mathrm{C} 3 \mathrm{H} / \mathrm{HeN}$ mice $\left(11 \pm 3 \mathrm{CFU} / 2 \times 10^{6}\right.$ cells $)$. Over $10^{5}$ times more bacteria $\left(4.1 \times 10^{6} \mathrm{CFU} / 2 \times 10^{6}\right.$ cells $)$, however, were recovered from the Kupffer cells of $\mathrm{C} 3 \mathrm{H} / \mathrm{HeJ}$ mice. Few unencapsulated bacteria were detected from the Kupffer cells of either strain of mouse ( 0 and $3 \pm 1 \mathrm{CFU} / 2 \times 10^{6}$ cells in $\mathrm{C} 3 \mathrm{H} / \mathrm{HeN}$ and $\mathrm{C} 3 \mathrm{H} / \mathrm{HeJ}$ mice, respectively), consistent with data obtained from cultures of liver homogenates.

Light and electron microscopy. Since strain Bort was cleared from the bloodstream of both $\mathrm{C} 3 \mathrm{H} / \mathrm{HeJ}$ and $\mathrm{C} 3 \mathrm{H} / \mathrm{HeN}$ mice, and was cultured from both liver homogenates and Kupffer cell preparations, we next determined whether there were any morphologic correlates within the Kupffer cell which would predict the resurgence of $E$. coli, strain Bort, in $\mathrm{C} 3 \mathrm{H} / \mathrm{HeJ}$ mice after their initial clearance. Mice were challenged with bacteria intraperitoneally and their liver sections were examined at 48 h using light and electron microscopy. With light microscopic examination, the livers of both strains of mice inoculated with $E$. coli, strain Bort showed normal hepatocytes. No inflammatory cells were seen either in portal areas or lobules. No bacteria were seen in the livers of $\mathrm{C} 3 \mathrm{H} / \mathrm{HeN}$ mice. In contrast, the livers of $\mathrm{C} 3 \mathrm{H} / \mathrm{HeJ}$ mice were remarkable for the presence of enlarged Kupffer cells that contained numerous phagocytized $E$. coli in the cytoplasm (Fig. 3 ).

Electron microscopic examination of the livers of $\mathrm{C} 3 \mathrm{H} / \mathrm{HeJ}$ mice revealed $E$. coli within expanded lysosomes of Kupffer cells (Fig. 4). In some cells, bacteria were undergoing division (Fig. $4 B$ ). After 48 h, Kupffer cells were packed with $E$. coli and sometimes contained 50-100 bacteria (Fig. 5). Replication of $E$. coli was so extensive that many liver cells were destroyed. $E$. coli were also seen in circulating monocytes (Fig. 6), although in smaller numbers (not exceeding 10 organisms per section of the cell) than in Kupffer cells.

In contrast to the observations with $\mathrm{C} 3 \mathrm{H} / \mathrm{HeJ}$ mice, examination of liver by light microscopy at any time after inoculation of $\mathrm{C} 3 \mathrm{H} / \mathrm{HeN}$ mice did not reveal any bacteria. With electron 


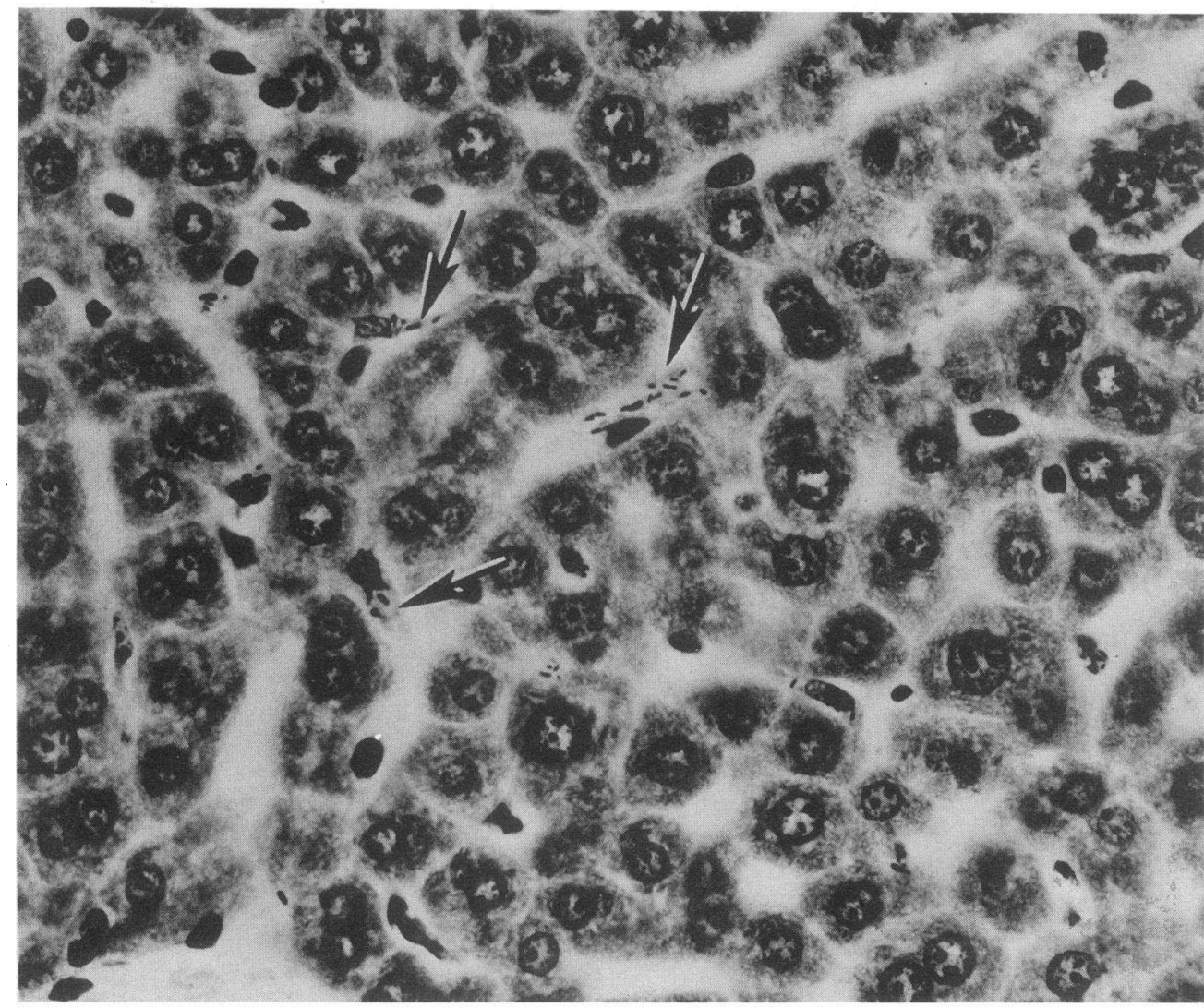

Figure 3. Light micrograph of $\mathrm{C} 3 \mathrm{H} / \mathrm{HeJ}$ mouse liver obtained at $48 \mathrm{~h}$ after the intraperitoneal inoculation with $\sim 100 \mathrm{CFU} E$. coli, strain Bort, and stained with modified Gram stain. Enlarged Kupffer cells contain numerous $E$. coli (arrows). Hepatocytes are normal, and there is no inflammation. $\times 190$.

microscopic examination, only single bacteria with atypical morphology reflecting bacterial degeneration were found in occasional Kupffer cells (Fig. 7, $A$ and $B$ ).

In vitro opsonophagocytic studies. The electron microscopic studies suggested that smooth LPS, K1-encapsulated phenotype $E$. coli were taken up by phagocytes of the $\mathrm{C} 3 \mathrm{H} / \mathrm{HeJ}$ mice. These mice, whose LPS-mediated responses were blocked, appeared unable either to kill the ingested bacteria or to prevent their active replication within phagolysosomes. These morphologic characteristics of the Kupffer cells of the $\mathrm{C} 3 \mathrm{H} / \mathrm{HeJ}$ mice, with bacteria replicating within the phagolysosome in contrast to the apparent destruction of these same bacteria within the phagolysosome of $\mathrm{C} 3 \mathrm{H} / \mathrm{HeN}$ mice, reflect the behavior of intracellular parasites within phagocytes that required further activation for intracellular killing (28). To study whether the activation of phagocytes was required to limit the infection, we next compared the ability of both Kupffer cells and peritoneal macrophages from the $\mathrm{C} 3 \mathrm{H} / \mathrm{HeJ}$ and $\mathrm{C} 3 \mathrm{H} / \mathrm{HeN}$ mice to kill $E$. coli, strain Bort, in an in vitro system. Neither strain Bort nor the K1-negative mutant were killed by serum alone.

Kupffer cells from both strains of mice that were preincubated in medium alone for $48 \mathrm{~h}$ were found to kill poorly after an additional 3-h incubation period with the bacteria (no reduction in the original bacterial dose $\left[1.08 \times 10^{5} \mathrm{CFU} / \mathrm{ml}\right]$ for the $\mathrm{C} 3 \mathrm{H} / \mathrm{HeN}$ cells and a reduction from $8.0 \times 10^{4}$ to 6.6 $\times 10^{4} \mathrm{CFU} / \mathrm{ml}[0.08 \mathrm{log}$ ] for $\mathrm{C} 3 \mathrm{H} / \mathrm{HeJ}$ cells, data not shown). Similarly, freshly isolated Kupffer cells from both $\mathrm{C} 3 \mathrm{H} / \mathrm{HeJ}$ and $\mathrm{C} 3 \mathrm{H} / \mathrm{HeN}$ mice were unable to kill bacteria in the absence of activation (data not shown). The addition of $50 \mathrm{U} / \mathrm{ml}$ IFN$\gamma$, a known activator of macrophages (28), during the preincubation period, however, resulted in a significantly increased killing of the challenge dose with both $\mathrm{C} 3 \mathrm{H} / \mathrm{HeN}$ and $\mathrm{C} 3 \mathrm{H} /$ $\mathrm{HeJ}$ cells (to 400 and $600 \mathrm{CFU} / \mathrm{ml}$, respectively, a > $2 \mathrm{log}$ reduction).

When interferon-activated peritoneal macrophages from both strains of mice were used in place of Kupffer cells, a reduction in bacterial challenge dose was also observed $(\geq 1.5$ $\log$ reduction for both strains of mice respectively, Table II, experiment 1) similar to that observed with Kupffer cells. This macrophage-mediated bacterial killing required the presence of normal human serum. Since little bacterial killing was observed in the absence of interferon treatment, any activation of peritoneal macrophages during their elicitation by proteose-peptone irritation was apparently not sufficient by itself to activate the cells. As was true for Kupffer cells, no bacterial killing was observed when freshly isolated peritoneal macrophages were used (data not shown). In view of the similarity in the ability of Kupffer cells and elicited peritoneal macrophages to mediate the killing of the bacteria, we performed subsequent studies with the peritoneal macrophages.

Since the morphologic characteristics of $E$. coli within the Kupffer cells suggested the need for activation, and the initial in vitro experiments were consistent with this hypothesis, we examined further the requirements for the killing of these bacteria by activated phagocytes, by focussing on the ability of another known activator of macrophages, LPS, to prime the macrophages of $\mathrm{C} 3 \mathrm{H} / \mathrm{HeJ}$ and $\mathrm{C} 3 \mathrm{H} / \mathrm{HeN}$ mice. While IFN- $\gamma$ and LPS were both able to activate the peritoneal macrophages of $\mathrm{C} 3 \mathrm{H} / \mathrm{HeN}$ cells for bactericidal kill (each $>2 \log$ reduction), only the interferon was able to induce much bacterial kill by $\mathrm{C} 3 \mathrm{H} / \mathrm{HeJ}$ macrophages $(2.3 \mathrm{log}$ reduction for interferon vs 0.66 $\log$ for LPS activation, Table II, experiment 2 ). Thus, the sus- 


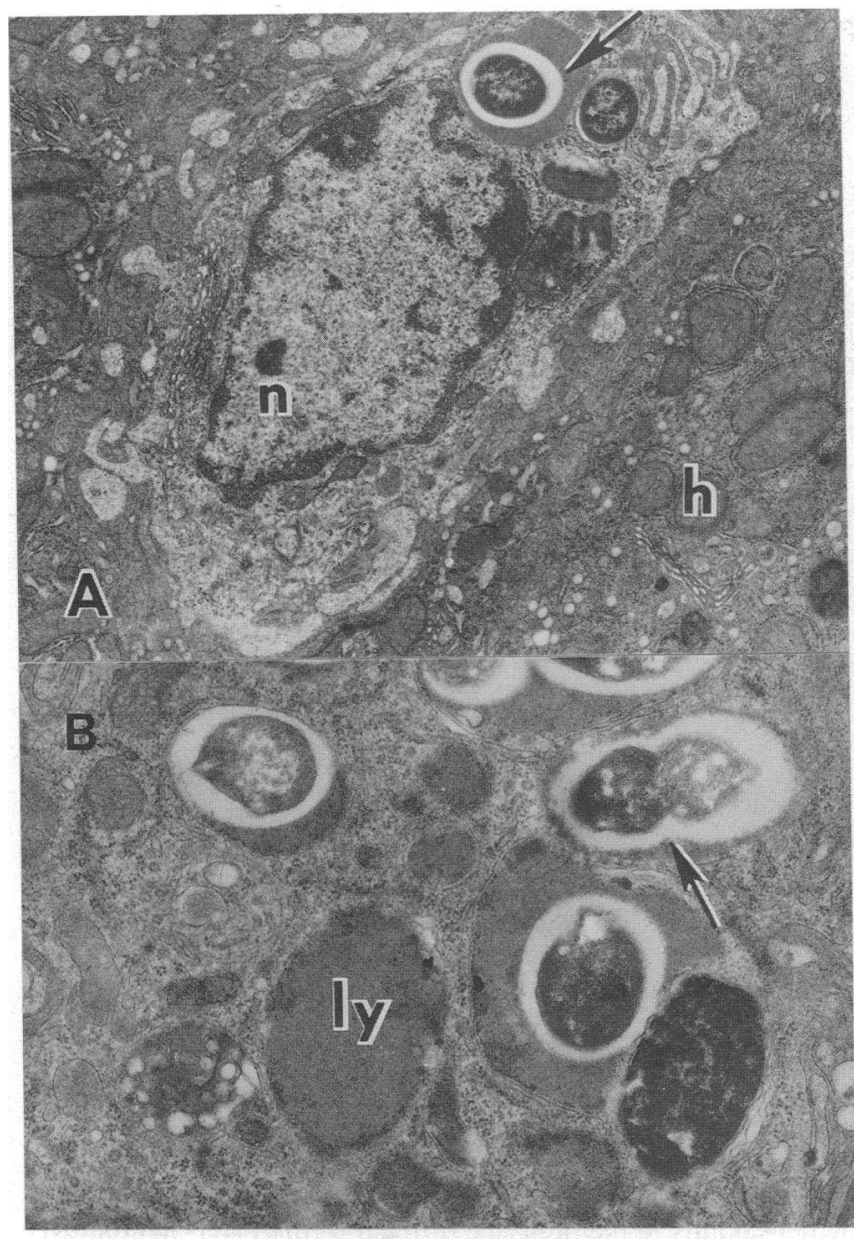

Figure 4. Electron micrograph of $\mathrm{C} 3 \mathrm{H} / \mathrm{HeJ}$ mouse liver $48 \mathrm{~h}$ after the intraperitoneal inoculation with $\sim 100 \mathrm{CFU} E$. coli, strain Bort. (A) $E$. coli surrounded with wide halo, presumably capsule, in an enlarged lysosome of a Kupffer cell (arrow). h, hepatocyte; $n$, nucleus of Kupffer cell. $\times 11,000$. $(B)$ Higher power micrograph of another Kupffer cell containing several $E$. coli. Arrow shows a dividing $E$. coli. ly, lysosome. $\times 19,800$.

ceptibility of $\mathrm{C} 3 \mathrm{H} / \mathrm{HeJ}$ mice to lethal infection by bacteria of a specific phenotype is not due to an intrinsic defect of the either the Kupffer cell or peritoneal macrophage phagocytes to be activated to kill these bacteria, but more likely reflects the inability of the $\mathrm{C} 3 \mathrm{H} / \mathrm{HeJ}$ phagocyte to be activated through an LPS-mediated pathway (or by another agonist that shared that pathway).

In addition to IFN- $\gamma$, other cytokines are also able to prime the peritoneal macrophages of $\mathrm{C} 3 \mathrm{H} / \mathrm{HeJ}$ mice for bacterial killing (Table III). M-CSF, IL-1, and TNF each activated these peritoneal macrophages in a dose-dependent manner. As might be anticipated from the protective effects of this cytokine combination in vivo (18), combinations of IL-1 and TNF have synergistic effects when used at concentrations that were ineffective when used alone.

Since $\mathrm{C} 3 \mathrm{H} / \mathrm{HeJ}$ mice that were pretreated with cytokines in vivo were able to resist lethal bacterial infection, and since phagocytes from these mice that were stimulated with IFN- $\gamma$, IL-1, TNF, and M-CSF were able to efficiently kill these bacteria in vitro, we next assessed whether activation of $\mathrm{C} 3 \mathrm{H} / \mathrm{HeJ}$ phagocytes in vivo would similarly affect mortality. After pre- treatment of mice with BCG, a known activator of macrophages (29), mice were able to withstand 10 times the challenge inoculum that caused $100 \%$ mortality in non-BCG-treated mice (Table IV). Thus, $\mathrm{C} 3 \mathrm{H} / \mathrm{HeJ}$ phagocytes that were activated in vitro with IFN- $\gamma$, M-CSF, IL-1, and TNF or in vivo with BCG were capable of killing $E$. coli $\mathrm{O} 18: \mathrm{K} 1: \mathrm{H} 7$, strain Bort. $\mathrm{C} 3 \mathrm{H} / \mathrm{HeN}$ mice given a challenge of 3,240 CFU Bort cells (severalfold below its $\mathrm{LD}_{50}[18]$ ) in the absence of any pretreatment with BCG all survived (data not shown).

In an earlier study, we had demonstrated that pre-treatment of $\mathrm{C} 3 \mathrm{H} / \mathrm{HeJ}$ mice with a combination of recombinant murine IL- $1 \alpha$ and TNF afforded significant protection from lethal sepsis (18). Consequently, when we showed in this study that the in vitro killing of $E$. coli $\mathrm{O} 18: \mathrm{K} 1$ strain Bort by cytokine-activated mononuclear cells required fresh normal serum, we decided to determine if the in vivo protection afforded by cytokine pretreatment also required an intact complement system. Mice pretreated with the combination of cytokines had increased survival from lethal bacterial challenge ( $9 / 13$ survived in the cytokine group vs $1 / 13$ without cytokine treatment, $P=0.004$, two-tailed Fisher exact test); however, those mice pretreated with CVF to deplete complement before cytokine treatment were unable to resist lethal infection $(2 / 14$ survived in the CVF and cytokine treatment group vs $9 / 13$ survivors in the cytokinetreated group that did not receive CVF, $P=0.006$, two-tailed Fisher exact test). CVF treatment alone did not induce death in these mice. Thus, as was true for the in vitro killing of $E$. coli, enhancement of host defenses by the cytokines IL-1 and TNF could not confer increased protection in the absence of an intact complement system.

Flow cytometry studies. Previous studies have demonstrated that the ability of monocyte-derived macrophages to phagocytize Mycobacterium leprae involves the expression of CR4, a maturation-dependent cell surface marker (CD11c/CD18; p150.95) that is minimally expressed on monocytes (30). In our Kupffer cell preparation $>90 \%$ of freshly isolated cells from both $\mathrm{C} 3 \mathrm{H} / \mathrm{HeN}$ and $\mathrm{C} 3 \mathrm{H} / \mathrm{HeJ}$ mice expressed $\mathrm{CR} 4$ with mean channel fluorescence (MCF) of 206 and 129 respectively (Fig. 8). Upon incubation of cells from both strains of mice in vitro, however, there was a decreased expression of CR4 in the absence of LPS or IFN- $\gamma$ after $48 \mathrm{~h}$. Addition of interferon to the incubation media resulted in a nearly one log increase in percentage of CR4-expressing cells in $\mathrm{C} 3 \mathrm{H} / \mathrm{HeJ}$ cells (Fig. 8 $D$ ), but a decrease in MCF (from 129 to 87). In contrast, incubation of $\mathrm{C} 3 \mathrm{H} / \mathrm{HeN}$ Kupffer cells with interferon was associated with a decrease in CR4 expression (both in terms of MCF and percentage of population expressing CR4; Fig. $8 \mathrm{C}$ ). Exposure to LPS did increase the CR4 expression in the Kupffer cells of $\mathrm{C} 3 \mathrm{H} / \mathrm{HeN}$ mice. As expected, the percentage of $\mathrm{C} 3 \mathrm{H} /$ HeJ Kupffer cell population expressing CR4 upon exposure to LPS was similar to the expression measured with incubation in medium alone. This differential induction of surface markers after stimulation with LPS and interferon suggests the possibility that these two reagents, each capable of activating phagocytes to kill bacteria, do so through different signal transduction pathways. Since LPS and interferon each activate the phagocytes to kill $E$. coli, strain Bort, yet have divergent effects on CR4 expression, it is unlikely that the CR4 receptor is as critical to host defenses of $E$. coli as it is to host defenses against $M$. leprae.

Only 27 and $16 \%$ of peritoneal macrophages freshly isolated from $\mathrm{C} 3 \mathrm{H} / \mathrm{HeJ}$ and $\mathrm{C} 3 \mathrm{H} / \mathrm{HeN}$ mice, respectively, expressed 


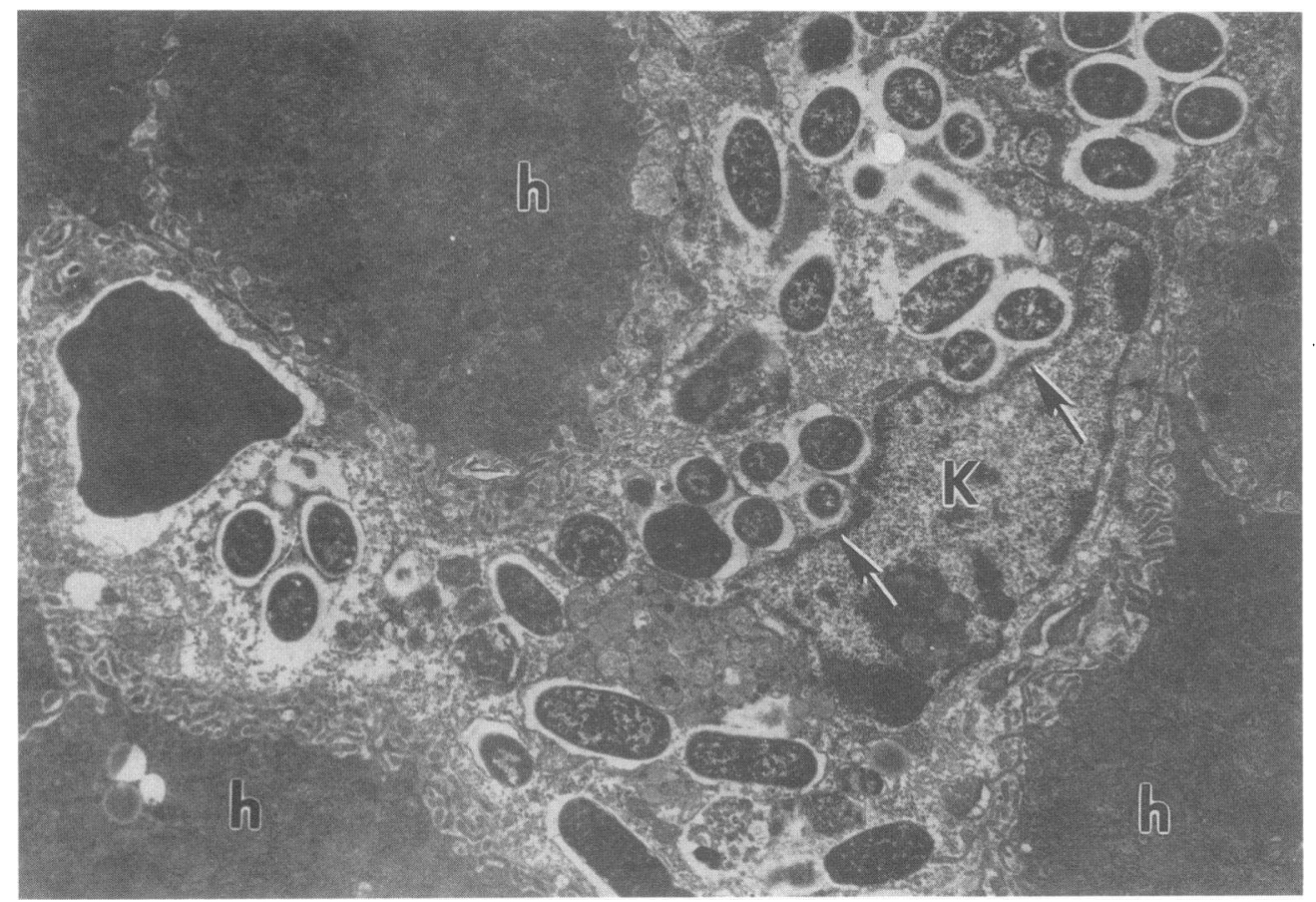

Figure 5. Electron micrograph of $\mathrm{C} 3 \mathrm{H} / \mathrm{HeJ}$ mouse liver, $48 \mathrm{~h}$ after inoculation. Kupffer cell is heavily infected with $E$. coli. Several replicating bacteria indent the nucleus (arrows). $\mathrm{K}$, Kupffer cell; h, hepatocyte, $\times 11,000$.

CR4 on their surface (data not shown). Incubation of these cells for $48 \mathrm{~h}$ in medium alone resulted in increased expression of CR4 (76 and 34\%, respectively). Thus, peritoneal macrophages cultured in vitro became more like Kupffer cells in their expression of the maturation-dependent marker, CR4.

Differing host defense mechanisms for K1-unencapsulated mutant. As expected from the ability of non-stimulated mice to clear the unencapsulated Bort mutant (see above), cytokinemediated enhancement of the macrophages had little effect on the mortality of $\mathrm{C} 3 \mathrm{H} / \mathrm{HeJ}$ mice infected with this $\mathrm{K} 1$-negative mutant (Table V). With in vitro bactericidal assays, the K1negative mutant of strain Bort was serum resistant, but, unlike the parental strain, was highly susceptible to killing mediated by neutrophils in the presence of fresh serum (26). In contrast,

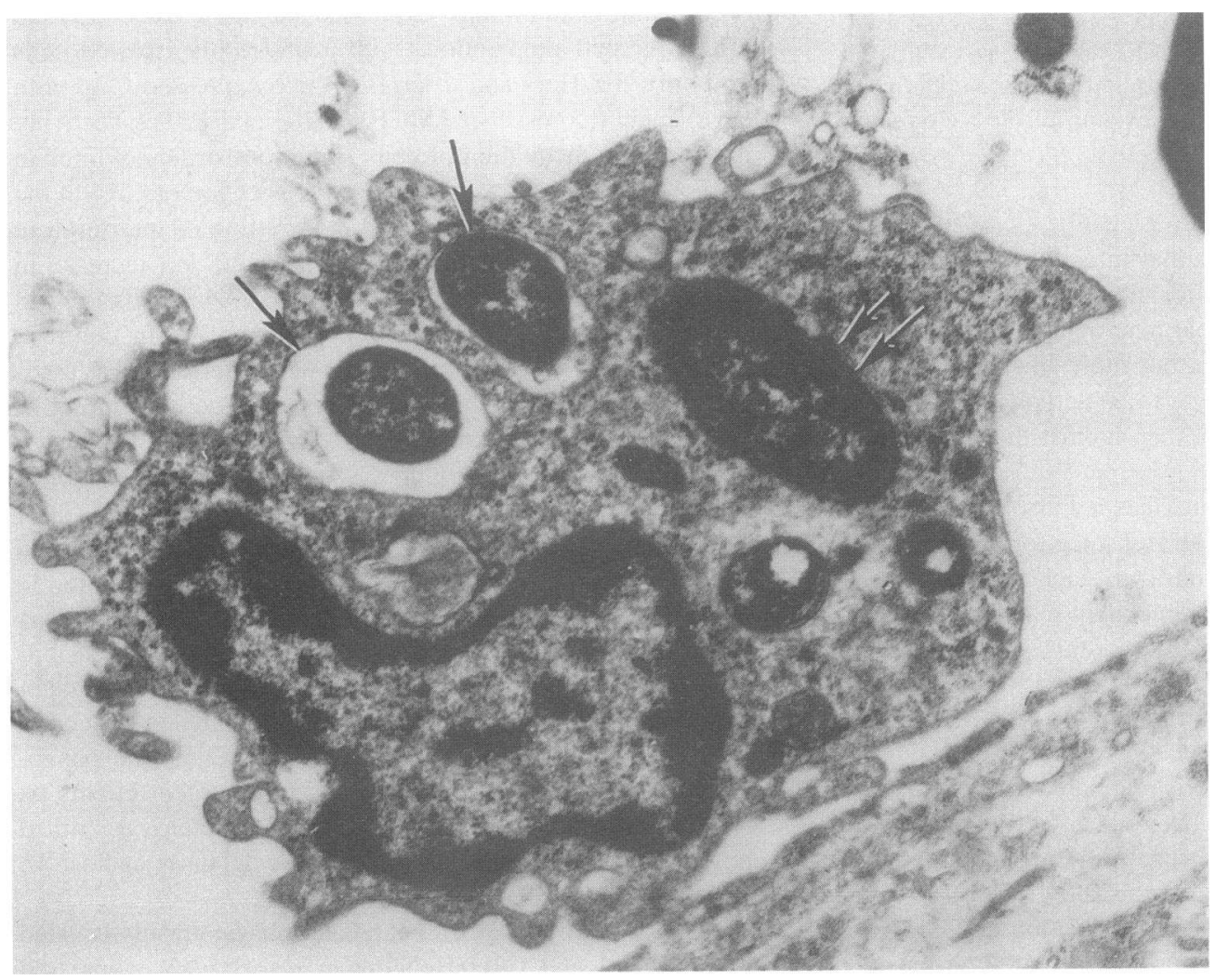

Figure 6. Electron micrograph of a circulating monocyte in a small vessel of the liver of a $\mathrm{C} 3 \mathrm{H} / \mathrm{HeJ}$ mouse after the intraperitoneal inoculation with $\sim 100$ CFU E. coli. containing E. coli in the phagosomes (arrows) and lysosome (double arrow). $\times 23,000$. 

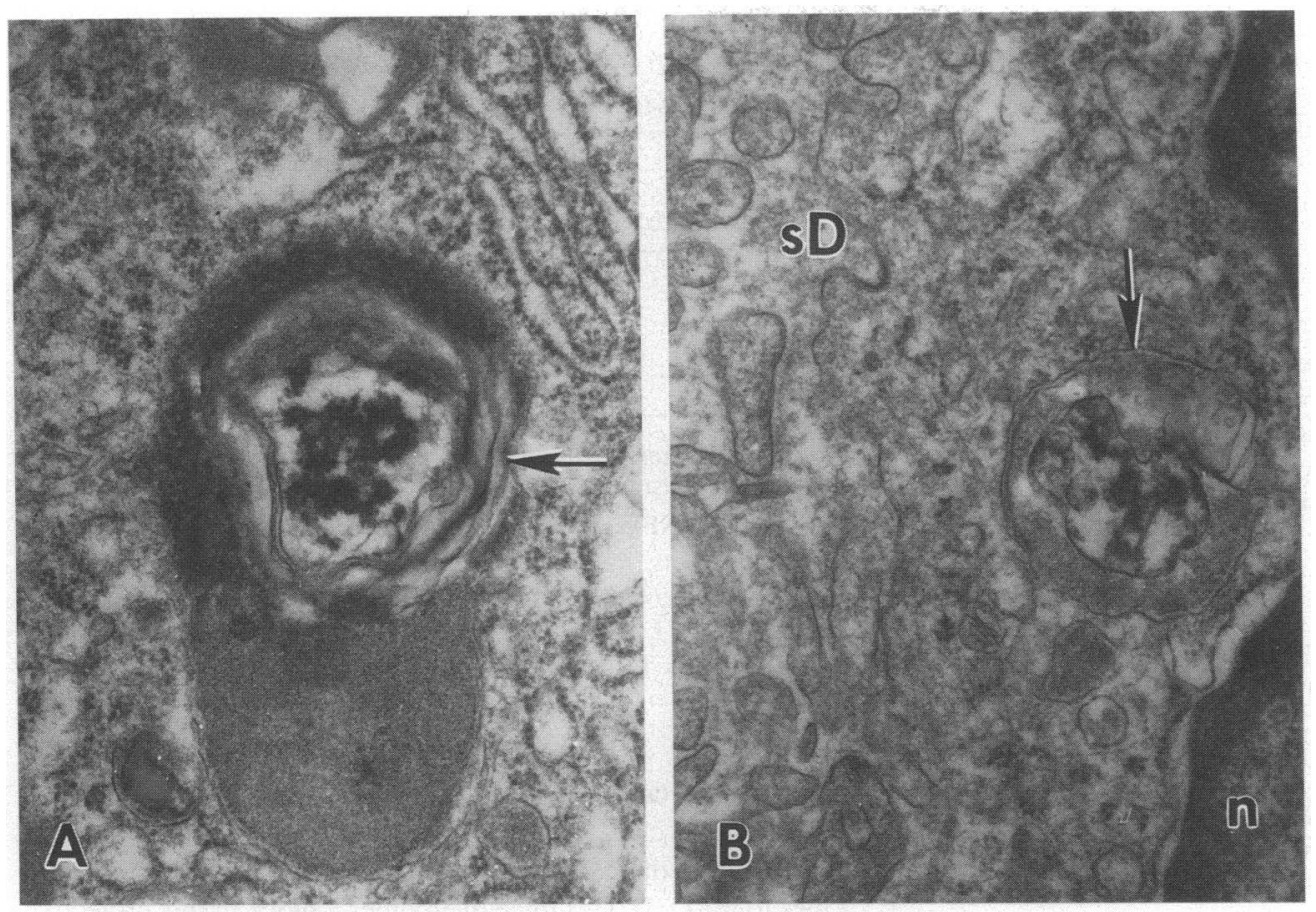

Figure 7. Electron micrograph of Kupffer cells in a C3H/HeN mouse liver. $(A)$ Kupffer cell contains a single degenerated $E$. coli. Only remnants of bacterial cell and cellular membranes are left in a phagolysosome

(arrow). (B) Disintegration of $E$. coli in the vesicle near indented nucleus (arrow). n, nucleus of Kupffer cell; sD, space of Disse. $\times 36,000$

the peritoneal macrophage-mediated killing of this mutant required the phagocyte to be activated in a manner similar to that needed for killing of the parental Bort strain. In the absence of treatment with interferon, there was no killing of the K1-negative mutant $(66,000 \mathrm{CFU} / \mathrm{ml}$ at 0 time to $70,000 \mathrm{CFU} / \mathrm{ml}$ at 3 h). However, when peritoneal macrophages were stimulated with $\mathrm{r}$ muIFN- $\gamma(50 \mathrm{U} / \mathrm{ml})$ for $48 \mathrm{~h}$, the bacterial inoculum was reduced to $900 \mathrm{CFU} / \mathrm{ml}$ in $3 \mathrm{~h}$, a $99 \%$ reduction. Thus,

Table II. Peritoneal Macrophages of $\mathrm{C} 3 \mathrm{H} / \mathrm{HeJ}$ and $\mathrm{C} 3 \mathrm{H} / \mathrm{HeN}$ Mice both Mediate Killing of E. coli 018:K1, Strain Bort Upon Stimulation

\begin{tabular}{|c|c|c|c|}
\hline \multirow[b]{2}{*}{ Cells } & \multirow[b]{2}{*}{ Condition } & \multicolumn{2}{|c|}{ CFUs $/ \mathrm{ml}\left(\times 10^{3}\right)$} \\
\hline & & Experiment 1 & Experiment 2 \\
\hline \multirow[t]{5}{*}{$\mathrm{C} 3 \mathrm{H} / \mathrm{HeN}$} & 0 time & $96^{*}$ & 88 \\
\hline & $3 \mathrm{~h}$ & $90 \quad(6)^{\ddagger}$ & $92 \quad(0)$ \\
\hline & $3 h+I F N$ & $3 \quad(97)$ & $0.8(99.1)$ \\
\hline & 3 h, + IFN, No NHS & $64 \quad(33)$ & ND \\
\hline & $3 \mathrm{~h}+$ LPS & ND & $0.3(99.7)$ \\
\hline \multirow[t]{5}{*}{ C3H/HeJ } & 0 time & 110 & 100 \\
\hline & $3 \mathrm{~h}$ & $90 \quad(18)$ & $96 \quad(4)$ \\
\hline & $3 \mathrm{~h}+\mathrm{IFN}$ & $0.9(99.2)$ & $0.5(99.5)$ \\
\hline & 3 h + IFN, No NHS & $34 \quad(69)$ & ND \\
\hline & $3 \mathrm{~h}+$ LPS & ND & $22 \quad(78)$ \\
\hline
\end{tabular}

* Peritoneal macrophages $\left(2 \times 10^{5} /\right.$ well $)$ were incubated at $37^{\circ} \mathrm{C}$ in $5 \%$ $\mathrm{CO}_{2}$ in the presence of media alone, $\mathrm{r}$ muIFN- $\gamma$ (IFN, $50 \mathrm{U} / \mathrm{ml}$ ), or lipopolysaccharide (LPS, $10 \mu \mathrm{g} / \mathrm{ml}$ ). After extensive washing, bacteria were added in the presence or absence of fresh normal human serum (NHS). The number of bacterial CFU per well were determined at 0 time and $3 \mathrm{~h}$. Data are from a single representative experiment with each variable run in triplicate. ${ }^{\ddagger}$ Percentage of 0 time bacterial inoculum killed given in parentheses. this $\mathrm{K} 1$ capsule-negative $E$. coli phenotype appears to be adequately handled by host defense mechanisms different from those which handle the $\mathrm{K} 1$ capsule-positive parent.

\section{Discussion}

Our studies demonstrate that a clinically relevant isolate of $E$. coli with a phenotype that enables it to evade both serummediated bacteriolysis and neutrophil-mediated killing can be eliminated by a LPS-initiated host defense mechanism.

We had earlier shown that $\mathrm{C} 3 \mathrm{H} / \mathrm{HeJ}$ mice are 10,000 times

Table III. Activation of Peritoneal Macrophages from $\mathrm{C} 3 \mathrm{H} / \mathrm{HeJ}$ Mice by Recombinant Cytokines

\begin{tabular}{lcc}
\hline \multicolumn{1}{c}{ Pretreatment } & CFU $\left(\times 10^{3} / \mathrm{ml}\right)$ & Percent kill \\
\hline None, 0 time & 74 & - \\
None $3 \mathrm{~h}$ & $76^{*}$ & 0 \\
LPS, $10 \mu \mathrm{g} / \mathrm{ml}$ & 64 & 10 \\
IFN, $100 \mathrm{U} / \mathrm{ml}$ & 3.6 & 95 \\
M-CSF, $100 \mathrm{ng} / \mathrm{ml}$ & 4.9 & 93 \\
10 & 32 & 57 \\
IL-1, $100 \mathrm{U} / \mathrm{ml}$ & 2.6 & 96 \\
50 & 6.8 & 91 \\
25 & 50 & 32 \\
TNF, $1,000 \mathrm{U} / \mathrm{ml}$ & 8.3 & 89 \\
300 & 56 & 24 \\
100 & 64 & 14 \\
IL-1 $25 \mathrm{U} / \mathrm{ml}+$ TNF $100 \mathrm{U} / \mathrm{ml}$ & 22 & 70 \\
IL-1 $25 \mathrm{U} / \mathrm{ml}+$ TNF $300 \mathrm{U} / \mathrm{ml}$ & 14 & 81 \\
\end{tabular}

IFN, recombinant murine IFN- $\gamma$; IL-1, recombinant human IL-1 $\alpha$; TNF $=$ recombinant murine TNF- $\alpha .{ }^{*}$ All subsequent data are $\mathrm{CFU} / \mathrm{ml}$ obtained from samples incubated for $3 \mathrm{~h}$. 
Table IV. Administration of BCG to C3H/HeJ Mice Protects against Lethal Infection with E. coli O18:K1:H7, Strain Bort

\begin{tabular}{ccc}
\hline Pre-treatment & Inoculum (CFUs) & Survival (survival/total) \\
\hline None & 324 & $0 / 3 *$ \\
BCG & 1080 & $5 / 5$ \\
BCG & 3240 & $4 / 4$
\end{tabular}

* $\mathrm{C} 3 \mathrm{H} / \mathrm{HeJ}$ mice were treated intraperitoneally with $2 \times 10^{5} \mathrm{CFU}$ live BCG. 7-10 d later they were challenged intraperitoneally with the indicated amounts of bacteria, and mortality followed for $14 \mathrm{~d}$. Pretreatment with BCG significantly enhanced survival after bacterial challenge with $1,080 \mathrm{CFU}(P=0.018$, two-tailed Fisher exact test) and after $3,240 \mathrm{CFU}(P=0.029)$.

more susceptible to lethal infection with this smooth LPS, K1encapsulated $E$. coli than are $\mathrm{C} 3 \mathrm{H} / \mathrm{HeN}$ mice, and that the administration of recombinant cytokines can restore host defenses in $\mathrm{C} 3 \mathrm{H} / \mathrm{HeJ}$ mice against this strain of $E$. coli to a level observed for $\mathrm{C} 3 \mathrm{H} / \mathrm{HeN}$ mice (18). While it is possible that LPS-hyporesponsive $\mathrm{C} 3 \mathrm{H} / \mathrm{HeJ}$ mice have additional defects in host defenses, these data are consistent with the hypothesis

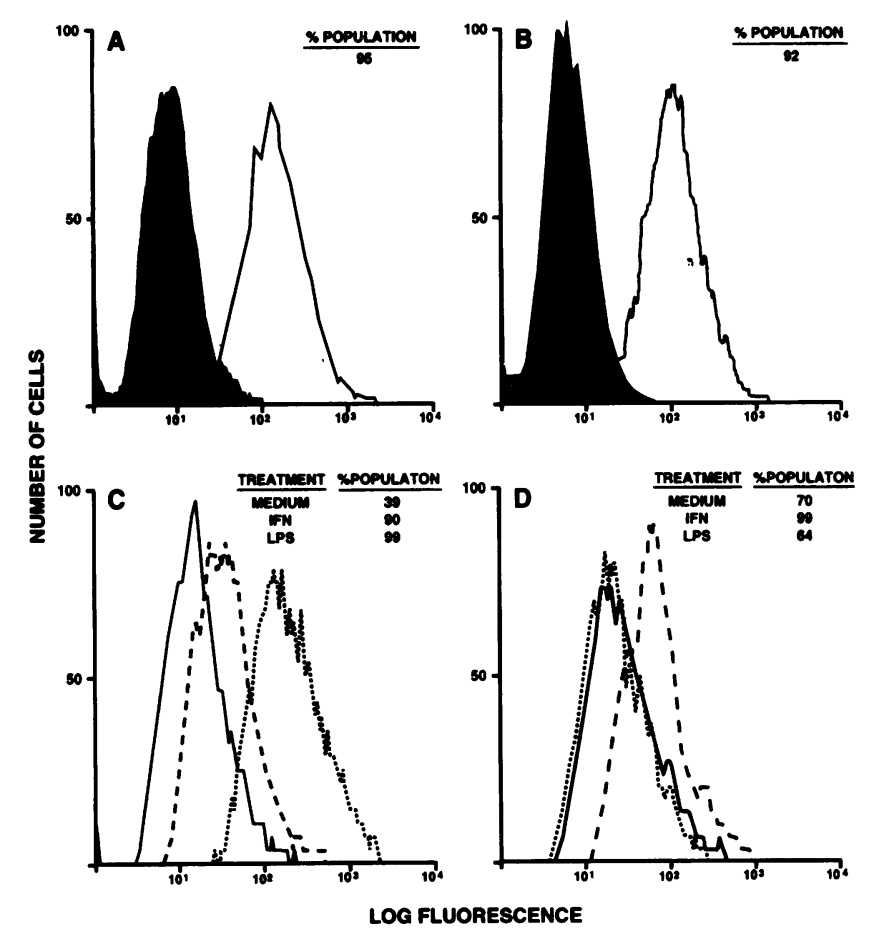

Figure 8. Flow cytometric analysis of CR4 expression in Kupffer cells isolated freshly from $\mathrm{C} 3 \mathrm{H} / \mathrm{HeN}(A)$ and $\mathrm{C} 3 \mathrm{H} / \mathrm{HeJ}(B)$ mice, and in Kupffer cells incubated for $48 \mathrm{~h}$ in medium alone, recombinant murine IFN- $\gamma(100 \mathrm{U} / \mathrm{ml})$, or LPS from $E$. coli $018(10 \mu \mathrm{g} / \mathrm{ml})(C$ and $D$, $\mathrm{C} 3 \mathrm{H} / \mathrm{HeN}$ and $\mathrm{C} 3 \mathrm{H} / \mathrm{HeJ}$, respectively). Solid curves are fluorescent intensity of isotypic mAb controls. Curves outlined by solid lines are the fluorescent intensities of CR4-mAb-stained cells that were freshly isolated $(A$ and $B)$ and CR4-stained cells that were incubated in media $(C$ and $D)$. The fluorescent intensities of Kupffer cells stained with CR4 mAb after treatment with IFN- $\gamma$ or LPS are indicated by curves drawn with dotted ( $L P S)$ or broken (IFN) lines. The percentage of the Kupffer cell population expressing CR4 is indicated in the inset of each panel.
Table V. Pretreatment of $\mathrm{C} 3 \mathrm{H} / \mathrm{HeJ}$ Mice with Combination of Recombinant IL-1/TNF Before Challenge with Avirulent E. coli Bort Mutant (O18: $\mathrm{K}-$ )

\begin{tabular}{ccc}
\hline & \multicolumn{2}{c}{ Survival (number/total) } \\
\cline { 2 - 3 } Challenge dose $\left(\mathrm{LD}_{50} \mathrm{~s}\right)$ & No pretreatment & IL-1/TNF pretreatment* \\
\hline 0.5 & $9 / 10$ & $10 / 10$ \\
1.0 & $7 / 15$ & $10 / 15^{\text {ns }}$ \\
$2-4$ & $1 / 3$ & $2 / 8^{\text {ns }}$ \\
\hline
\end{tabular}

* Numbers represent survival/total animals in the group. Mice were pretreated with $500 \mathrm{U}$ recombinant murine IL-1 $\alpha$ and $25 \mathrm{ng}$ of recombinant murine TNF- $\alpha$ (Genzyme Corp., Boston, MA). Data are two separate experiments, each with similar results, combined. There was no significant difference in mortality between the two groups after challenge with $0.5,1.0 \mathrm{LD}_{50}(P=0.46$, two-tailed Fisher exact test $)$ or after $2-4 \mathrm{LD}_{50}(P=1.0)$.

that an important host protective mechanism that results in the generation of cytokines is mediated through an LPS-dependent pathway, and that the provision of exogenous recombinant cytokines to the $\mathrm{C} 3 \mathrm{H} / \mathrm{HeJ}$ mice overcomes a block in this protective pathway. Since there was no difference in susceptibility to lethal infection between the two strains of mice for a K1-negative smooth LPS mutant, this cytokine-mediated pathway was considered to be of less importance for host defenses against bacteria lacking capsule (18). Rather, neutrophils in conjunction with fresh serum were sufficient for the effective in vitro killing of this K1-negative $E$. coli $(18,26)$. Thus, a host may use a variety of defenses whose efficiency may depend on the phenotype of the bacteria that it encounters.

In the present study we also show that this increased lethality for $\mathrm{C} 3 \mathrm{H} / \mathrm{HeJ}$ mice is not the property of one uniquely virulent strain of $E$. coli, but rather is a general characteristic of $E$. coli that have a smooth LPS and K1 capsule (Table I). Clinical strains of $E$. coli that have a $\mathrm{K} 1$ capsule and the same $\mathrm{O}$ serogroup, but a part-rough LPS phenotype, or a smooth LPS phenotype of the same or other serogroups, but lacking the K1 capsule, do not have a similarly enhanced lethality for $\mathrm{C} 3 \mathrm{H} / \mathrm{HeJ}$ mice. Thus, these strains of bacteria would appear to be adequately handled by host defenses other than the LPS-initiated cytokinemediated pathway. This latter defense mechanism may therefore be considered a particularly important host defense for bacteria expressing specific surface phenotypes. The increased lethality for $\mathrm{C} 3 \mathrm{H} / \mathrm{HeJ}$ mice of $\mathrm{O} 1: \mathrm{K} 2$ Klebsiella pneumoniae, one of the few Klebsiella strains virulent for mice (31) and a strain highly resistant to neutrophil-mediated phagocytosis, suggests that this pathway may in fact be a more general host defense mechanism against bacteria having these specific complementand neutrophil-resistant phenotypes.

In vitro bactericidal assay permits the separate examination of the priming and triggering steps of this cytokine-mediated pathway. This host defense mechanism requires primed or activated macrophages. IFN- $\gamma$ as well as other cytokines were capable of activating macrophages in vitro from both LPS normoresponsive $(\mathrm{C} 3 \mathrm{H} / \mathrm{HeN})$ and LPS hyporesponsive $(\mathrm{C} 3 \mathrm{H} / \mathrm{HeJ})$ mice such that macrophages from both strains of mice were able to kill this $\mathrm{K} 1$-encapsulated, smooth LPS-bearing isolate of $E$. coli. Similarly, while $\mathrm{C} 3 \mathrm{H} / \mathrm{HeJ}$ mice were more susceptible to lethal infection with bacteria having a K1-encapsulated, 
smooth LPS phenotype when compared to $\mathrm{C} 3 \mathrm{H} / \mathrm{HeN}$ mice (18), activation of their phagocytes in vivo with BCG restored the ability of $\mathrm{C} 3 \mathrm{H} / \mathrm{HeJ}$ mice to resist this infection. Thus, there was no intrinsic inability of macrophages of $\mathrm{C} 3 \mathrm{H} / \mathrm{HeJ}$ to kill $E$. coli once these cells were activated either in vivo or in vitro.

In contrast, while another known activator of macrophages, LPS, could activate the macrophages of $\mathrm{C} 3 \mathrm{H} / \mathrm{HeN}$ mice to kill $E$. coli in vitro, it could not similarly activate macrophages from the $\mathrm{C} 3 \mathrm{H} / \mathrm{HeJ}$ mice (Table II, experiment 2 ). This inability of LPS to activate the bactericidal capability of macrophages of $\mathrm{C} 3 \mathrm{H} / \mathrm{HeJ}$ mice in vitro appears to be relevant in vivo inasmuch as electron microscopy (Figs. 4-6) revealed the presence of this $\mathrm{K} 1$-encapsulated $E$. coli within macrophages of $\mathrm{C} 3 \mathrm{H} / \mathrm{HeJ}$ mice, similar to what one would expect to observe in a macrophage that had not been activated. In contrast, the bacteria within the $\mathrm{C} 3 \mathrm{H} / \mathrm{HeN}$ macrophages were undergoing lysis (Fig. 7), similar to what one would expect of a bactericidal event within an activated macrophage. Taken together, these observations are consistent with the interpretation that macrophages of both $\mathrm{C} 3 \mathrm{H} / \mathrm{HeJ}$ and $\mathrm{C} 3 \mathrm{H} / \mathrm{HeN}$ mice are able to ingest $E$. coli, but that macrophages of $\mathrm{C} 3 \mathrm{H} / \mathrm{HeJ}$ mice are unable to kill these bacteria in vivo, unlike the case with $\mathrm{C} 3 \mathrm{H} / \mathrm{HeN}$ macrophages. Thus, while other agonists (such as BCG or IFN- $\gamma$ ) were capable of activating $\mathrm{C} 3 \mathrm{H} / \mathrm{HeJ}$ cells both in vitro and in vivo to provide a level of protection similar to that observed in $\mathrm{C} 3 \mathrm{H} /$ $\mathrm{HeN}$ mice, this was not occurring during the course of infection in $\mathrm{C} 3 \mathrm{H} / \mathrm{HeJ}$ mice (as it was during infection in the $\mathrm{C} 3 \mathrm{H} / \mathrm{HeN}$ mice). To account for these differences, we considered that perhaps the phagocytes had to be activated specifically by a LPS signal transduction pathway, and that only this LPS-initiated transduction pathway, or an agonist that may share this pathway, appears to be relevant to infection with these organisms in vivo. In fact, the different response in CR4 expression after exposure of Kupffer cells and peritoneal macrophages to LPS and interferon is preliminary evidence that these two agonists activate the cells by distinct signal transduction pathways. Further, we have observed in our laboratory that LPS modulates the cytokine repertoire of these mice in a manner that differs from that observed following BCG infection.

The microbicidal activity of activated macrophages from both strains of mice also requires fresh normal serum for optimal activity in the "triggering" step of the assay. The identity of this heat-labile serum factor and its mechanism of action are not clear. Preliminary evidence in our laboratory suggests that were it complement, it may facilitate uptake of the bacteria by the macrophage into intracellular compartments where the concentration of an effector molecule, such as nitric oxide, is greatest. Although heat-inactivated FCS was routinely included in the preincubation culture medium for the $48-72 \mathrm{~h}$, activation of $\mathrm{C} 3 \mathrm{H} / \mathrm{HeN}$ cells was also achieved by preincubating cells with LPS in the absence of any serum (data not shown). When fresh serum was omitted or heat-inactivated during the triggering step, however, no killing was observed.

The effector mechanism(s) by which LPS-mediated killing occurs is not clear but would appear to involve the generation of cytokines. The induction of cytokines by monocytes after exposure to LPS is amply documented $(32,33)$, and the administration of recombinant cytokines in vivo or in vitro as in this study to $\mathrm{C} 3 \mathrm{H} / \mathrm{HeJ}$ mice in vivo or its cells in vitro restored the microbicidal activity. Although some cytokines, such as interleukin-1, have been reported to increase the uptake of $E$. coli by phagocytes (34), the electron micrographs and clearance studies indicate that strain Bort is taken up by mononuclear phagocytes of $\mathrm{C} 3 \mathrm{H} / \mathrm{HeJ}$ mice. Rather, the LPS-mediated pathway appears to be primarily involved in the killing step(s). TNF has been shown to be a potent inducer of oxidative microbicidal pathways $(35,36)$. Preliminary evidence from our laboratory has shown that the bactericidal activity of activated $\mathrm{C} 3 \mathrm{H} / \mathrm{HeJ}$ macrophages may be mediated through a nitric oxide mechanism (37). Cytokines have been shown to have an important role in this effector pathway as well (38).

These findings confirm and extend previous studies that show the efficacy of specific host defense mechanisms is highly dependent on the surface characteristics of the target bacteria (4-11, 14-16, 19, 20). Bacteria that lack an acid polysaccharide capsule and complete LPS phenotype are easily killed by complement $(5,8)$. Bacteria that have a complete LPS or capsular polysaccharide are more easily killed by neutrophils and serum. The presence of either specific capsular polysaccharides, such as the K1 polysaccharide, or smooth LPS permit the bacteria to evade this mechanism, however (14). In this study we show that these latter bacteria can be killed by an additional host defense mechanism, but requires the generation of cytokines through an LPS-activated signal transduction pathway. Such a mechanism was not required for controlling infection by the K1-negative, smooth LPS mutant of strain Bort (Table V).

If LPS initiates important host defenses against invading pathogens by the induction of cytokine-mediated pathways, then its interruption by cytokine modulators (e.g., mAbs to the cytokines or cytokine receptor antagonists) could lead to accelerated infection and death upon exposure of the host to an invasive pathogen. Thus, in those patients (or animals) whose LPS-initiated pathways are under stress, but still intact, the administration of such modulators would be expected to produce detrimental results as observed both experimentally $(39,40)$ and in recent clinical trials with IL-1 receptor antagonist and anti-TNF $\mathrm{mAb}(41)$ where there was increased mortality in the treatment compared to the placebo group; however, in animals $(40,42,43)$ and patients whose LPSinitiated pathways have already escaped regulatory control and in whom autocrine activation has led to excessive amounts of cytokine production, cytokine inhibitors could be beneficial by returning the biologic system towards equilibrium. This may allow host regulatory systems to reassert control and lead to improved outcome. This is also consistent with what was observed in these clinical trials where patients most ill (i.e., highest APACHE scores) appeared to benefit from cytokine modulation with $\mathrm{IL}-1$ receptor antagonist and anti-TNF mAb. Under these conditions one would desire to administer only those amounts of cytokine modulator sufficient to restore balance, but not to completely interrupt these events. Thus a deleterious response to LPS, sepsis, may occupy one end of the same continuum occupied by a beneficial LPS-initiated pathway, such as the one described in the present studies.

In summary, we have described a mechanism by which the host can combat infection with $E$. coli and perhaps other bacteria previously thought to be handled primarily by the humoral immune system. This mechanism requires the activation of mononuclear phagocytes through an LPS signal transduction pathway, the generation of cytokines and the need for fresh serum during the triggering of the phagocytes upon encountering the bacteria. This pathway is utilized by the host in killing bacteria that have a smooth LPS phenotype and specific acid polysaccha- 
ride capsules that are most resistant to killing by previously described host defenses, but does not enhance activity against K1-negative strains that are efficiently handled by other host defense mechanisms. These studies emphasize the importance of bacterial surface characteristics in the interaction with specific host defense mechanisms, and also suggest a need to better define those infected patients who would benefit from anticytokine therapy.

\section{Acknowledgments}

We thank Lynnette Young for superb technical assistance and Edward Asafoadjei for the preparation of the electron micrographs. We appreciate the critical comments of Drs. George R. Siber and Evelyn KurtJones.

\section{References}

1. Rowley, D. 1954. The virulence of strains of Bacterium coli for mice. Br. J. Exp. Pathol. 35:528-538.

2. Medearis, D. N., Jr., and J. F. Kenny. 1968. Observations concerning the pathogenesis of $E$. coli infections in mice. J. Bacteriol. 101:534-540.

3. Smith, H. 1991. The influence of the host on microbes that cause disease. Proc. R. Soc. Lond. Se. B. Biol. Sci. 246:97-105.

4. Howard, C. J., and A. A. Glynn. 1971. The virulence for mice of strains of Escherichia coli related to the effects of $\mathrm{K}$ antigens on their resistance to phagocytosis and killing by complement. Immunology. 20:767-777.

5. Glynn, A. A., and C. J. Howard. 1970. The sensitivity to complement of strains of Escherichia coli related to their K antigens. Immunology. 18:331-346.

6. Wolberg, G., and C. W. De Witt. 1969. Mouse virulence of K(L) antigencontaining strains of Escherichia coli. J. Bacteriol. 100:730-737.

7. Smith, T. 1928. The relation of the capsular substance of $B$. coli to antibody production. J. Exp. Med. 48:351-61.

8. Rowley, D. 1968. Sensitivity of rough Gram-negative bacteria to the bactericidal action of serum. J. Bacteriol. 95:1647-1650.

9. Roantree, R. J. 1967. Salmonella O antigens and virulence. Annu. Rev. Microbiol. 21:443-66.

10. Wardlaw, A. C. 1963. The complement dependent bacteriolytic activity of normal human serum. II. Cell wall composition of sensitive and resistant strains. Can. J. Microbiol. 9:41-52.

11. Feingold, D. S. 1969. The serum bactericidal reaction. IV. Phenotypic conversion of Escherichia coli from serum-resistance to serum-sensitivity by diphenylamine. J. Infect. Dis. 120:437-444.

12. Roantree, R. J., and N. C. Pappas. 1960. The survival of strains of enteric baccilli in the blood stream as related to their sensitivity to the bactericidal effect of serum. J. Clin. Invest. 39:82-88.

13. Roantree, R. J., and L. A. Rantz. 1960. A study of the relationship of the normal bactericidal activity of human serum to bacterial infection. J. Clin. Invest. 39:72-81

14. Cross, A. A., P. Gemski, J. C. Sadoff, F. Orskov, and I. Orskov. 1984. The importance of the K1 capsule in invasive infections caused by Escherichia coli. J. Infect. Dis. 149:184-193.

15. McCabe, W. R., B. Kaijser, S. Olling, M. Uwaydah, and L. A. Hanson. 1978. Escherichia coli in bacteremia: $\mathrm{K}$ and $\mathrm{O}$ antigens and serum sensitivity of strains from adults and neonates. $J$. Infect. Dis. 138:33-41.

16. Olling, S. 1977. Sensitivity of Gram-negative bacilli to the serum bactericidal activity: a marker of the host-parasite relationship in acute and persisting infections. Scand. J. Infect. Dis. 10 (Suppl.):1-40.

17. Kreger, B. E., D. E. Craven, P. C. Carling, and W. R. McCabe. 1980. Gram-negative bacteremia. III. Reassessment of etiology, epidemiology and ecology in 612 patients. Am. J. Med. 68:332-355.

18. Cross, A. S., J. C. Sadoff, N. Kelly, E. Bernton, and P. Gemski. 1989. Pretreatment with recombinant murine tumor necrosis factor alpha/cachectin and murine interleukin-1 alpha protects mice from lethal bacterial infection. J. Exp. Med. 169:2021-2027.

19. Gemski, P., A. S. Cross, and J. C. Sadoff. 1980. K1-antigen associated resistance to the bactericidal activity of serum. FEMS Microbiol. Lett. 9:193197.
20. Kim, K. S., H. Itabashi, P. Gemski, J. Sadoff, R. L. Warren, and A. S. Cross. 1992. The K1 capsule is the critical determinant in the development of Escherichia coli meningitis in the rat. J. Clin. Invest. 90:897-905.

21. Reed, L. J., and H. Muench. 1938. A simple method of estimating fifty per cent endpoints. Am. J. Hyg. 27:493-497.

22. Kim, K. S., J. H. Kang, A. S. Cross, B. Kaufman, W. Zollinger, and J. Sadoff. 1988. Functional activities of monoclonal antibodies to the $O$ side chain of Escherichia coli lipopolysaccharides in vitro and in vivo. J. Infect. Dis. 157:4753.

23. Seguin, M. C., W. R. Ballou, and C. A. Nacy. 1989. Interactions of Plasmodium berghei sporozoites and murine Kupffer cells in vitro. J. Immunol. 143:1716-22.

24. Westphal, O., and K. Jann. 1965. Bacterial lipopolysaccharides. Extraction with pheno-water and further applications of the procedure. In Methods in Carbohydrate Chemistry. R. L. Whistler, editor. Academic Press, Inc., New York, San Francisco, London. 5:83-91.

25. Bortolussi, R., P. Ferrieri, B. Bjorksten, and P. G. Quie. 1979. Capsular $\mathrm{K} 1$ polysaccharide of Escherichia coli: relationship to virulence in newborn rats and resistance to phagocytosis. Infect. Immun. 25:293-298.

26. Vermeulen, C., A. S. Cross, W. R. Byrne, and W. Zollinger. 1988. Quantitative relationship between capsular content and killing of K-1 encapsulated Escherichia coli. Infect. Immun. 56:2723-2730.

27. Bull, C. G. 1916. Immunity factors in pneumococcus infection in the dog. J. Exp. Med. 24:7-25.

28. Murray, H. W. 1988. Interferon-gamma, the activated macrophage, and host defense against microbial challenge. Ann. Intern. Med. 108:595-608.

29. Hsueh, W., F. F. Sun, and S. Henderson. 1985. The biosynthesis of leukotriene $\mathrm{B}_{4}$, the predominant lipoxygenase product in rabbit alveolar macrophages, is enhanced during immune activation. Biochim. Biophys. Acta. 835:9297.

30. Schlesinger L. S., and M. A. Horwitz. 1991. Phagocytosis of Mycobacterium leprae by human monocyte-derived macrophages is mediated by complement receptors CR1 (CD35), CR3 (CD11b/CD18), and CR4 (CD11c/CD18) and IFN-gamma activation inhibits complement receptor function and phagocytosis of this bacterium. J. Immunol. 147:1983-1994.

31. Simoons-Smit, A. M., A. M. J. J. Verwey-Van Vught, I. Y. R. Kanis, and D. M. MacLaren. 1984. Virulence of Klebsiella strains in experimentally induced skin lesions in the mouse. J. Med. Microbiol. 17:67-77.

32. Cavaillon, J.-M., C. Fitting, N. Haeffner-Cavaillon, S. J. Kirsch, and H. S. Warren. 1990. Cytokine response by monocytes and macrophages to free and lipoprotein-bound lipopolysaccharide. Infect. Immun. 58:2375-2382.

33. Carswell, E. A., L. J. Old, R. L. Kassel, S. Green, N. Fiore, B. Williamson. 1975. An endotoxin-induced serum factor that causes necrosis of tumors. Proc. Natl. Acad. Sci. USA. 72:3666-3670.

34. Pelkonen, S., and G. Pluschke. 1989. Recombinant interleukin-1 stimulates clearance of Escherichia coli K1 bacteremia. Microb. Pathog. 6:415-424.

35. Berkow, R. L., D. Wang, J. W. Larrick, R. W. Dodson, and T. H. Howard. 1987. Enhancement of neutrophil superoxide production by preincubation with recombinant human tumor necrosis factor. J. Immunol. 139:3783-3791.

36. Nathan, C. F. 1987. Neutrophil activation on biological surfaces. Massive secretion of hydrogen peroxide in response to products of macrophages and lymphocytes. J. Clin. Invest. 80:1550-1560.

37. Cross, A. S., D. Hoover, and M. Garnick. 1991. Macrophage colony stimulating factor enhances host defenses against bacteria both in vivo and in vitro. Cytokine. 3:488. (Abstr. 231)

38. Green, S. J., S. Mellouk, S. L. Hoffman, M. S. Meltzer, and C. A. Nacy. 1990. Cellular mechanisms of nonspecific immunity to intracellular infection: cytokine-induced synthesis of toxic nitrogen oxides from L-arginine by macrophages and hepatocytes. Immunol. Lett. 25:15-20.

39. Tite, J. P., G. Dougan, and S. N. Chatfield. 1991. The involvement of tumor necrosis factor in immunity to Salmonella infection. J. Immunol. 147:3161 3164 .

40. Mancilla, J., P. Garcia, and C. A. Dinarello. 1993. The interleukin-1 receptor antagonist can either reduce or enhance the lethality of Klebsiella pneumoniae sepsis in newborn rats. Infect. Immun. 61:926-932.

41. Stone, R. 1994. Search for sepsis drugs goes on despite past failures. Science (Wash. DC). 264:365-367.

42. Tracey, K. J., Y. Fong, D. G. Hesse, K. R. Manogue, A. T. Lee, G. C. Kuo, S. F. Lowry, and A. Cerami. 1987. Anti-cachectin/TNF monoclonal antibodies prevent septic shock during lethal bacteremia. Nature (Lond.). 330:662-664.

43. Ohlsson, K., P. Bjork, M. Bergenfeldt, R. Hageman, and R. C. Thompson. 1990. Interleukin-1 receptor antagonist reduces mortality from endotoxin shock. Nature (Lond.). 348:550-552. 